\title{
Can the Adoption of Organic Farming Be Predicted by Biogeographic Factors? A French Case Study
}

\author{
Marco Pautasso ${ }^{1, \dagger, *}$, Anja Vieweger ${ }^{2}$ and A. Márcia Barbosa ${ }^{3}$ \\ ${ }^{1}$ Animal and Plant Health Unit, European Food Safety Authority (EFSA), Parma, Italy \\ 2 Organic Research Centre, Elm Farm, Hamstead Marshall, Newbury, UK \\ ${ }^{3}$ Centro de Investigação em Biodiversidade e Recursos Genéticos (CIBIO), InBIO Research Network in Biodiversity and \\ Evolutionary Biology, University of Évora, Portugal \\ * Corresponding author: E-Mail: marpauta@gmail.com; Tel.: +39 521036775 \\ $\dagger$ The positions and opinions presented in this article are those of the authors alone and are not intended to represent the \\ views or scientific works of EFSA.
}

Submitted: 13 January 2016 | In revised form: 21 April 2016 | Accepted: 9 June 2016 | Published: 29 June 2016

\begin{abstract}
Organic farming adoption is on the rise in many countries, due to the increased awareness of farmers, citizens, governments and other stakeholders of its more sustainable nature. Various studies have investigated the socio-economic drivers (e.g., consumer demand, support measures, agricultural policies) of organic farming adoption, but less attention has been paid to whether biogeographic factors could also be associated with variation in rates of organically managed farms in certain regions within countries. We investigate whether biogeographic factors are associated with variation in the proportion of land under organic farming in French departments. The proportion of land under organic farming increased with decreasing latitude and increasing department area. Non-significant factors were number of plant taxa, proportion of Natura 2000 protected areas, connectivity, longitude, altitude and department population. These results were robust to controlling for spatial autocorrelation. Larger and southern French departments tend to have a greater adoption of organic farming, possibly because of the more extensive nature of agriculture in such regions. Biogeographic factors have been relatively neglected in investigations of the drivers of organic farming adoption, but may have an important explanatory value.
\end{abstract}

Keywords: biodiversity; France, human population; land sharing; macroecology; organic farming; plant species richness; protected areas; spatial autocorrelation; sustainable development

\section{Introduction}

Organic farming is on the rise globally [1]. Between 2001 and 2011, agricultural land under organic management increased from nearly 16 to over 37 million hectares worldwide [2]. This trend is also reflected in the market for organ- ically grown produce; during the same decade, the global organic market grew by $170 \%$, with sales reaching nearly 63 billion US\$ in 2011 [3]. In 2011, France (3.8 billion Euros) was the second largest market for organic products in Europe (21.5 billion Euros) [4].

Organic farming aims to reconnect agriculture with na- 
ture and biodiversity, making use of natural systems and cycles and reducing external inputs (for example, growing a wider variety of crops and using natural ways to reduce pest populations, e.g. rotations). Industrial agriculture is currently one of the greatest threats to biodiversity [5-7]. Several studies have shown that organic farming benefits biodiversity, because of its less intensive cultivation practices [8-14] (see also [15]).

So far, studies investigating factors driving organic farming adoption have focused on socio-economic factors (e.g., agricultural policies, consumer demand, support measures and networks) [16-19]. However, given the connection of organic farming with nature, it could also be expected that the presence of organic farming co-varies with regional variation in biodiversity, as was shown at the landscape level [20]. Given that large-scale variation in biodiversity is in turn associated with biogeographic factors such as latitude, area and human population [21-24], it is reasonable to expect that also regional patterns in organic farming adoption will tend to be associated with such biogeographic factors.

This study aims to test this hypothesis by using data on organic farming adoption from French departments, together with some key biogeographic factors. Our main question was: is organic farming more likely to be adopted in regions with an already higher presence of biodiversity? More generally, can biogeographic factors help predict patterns in organic farming adoption across regions?

\section{Material and Methods}

Data on the proportion of agricultural land under organic farming (2008) for the 96 French metropolitan departments (with exception of Paris: data not available) were obtained from the website for sustainable development of the French government (http://www.statistiques. developpement-durable.gouv.fr/). From the same website, data for each French department were obtained on landscape connectivity (average size of natural habitats; 2006), the proportion of Natura 2000 protected areas (2009), the total area and human population (2011). Altitude was obtained from [25] as a raster map at ca. $1 \mathrm{~km}^{2}$ resolution, and averaged at French departments using the zonal statistics plugin of QGIS 2.6 [26] and an administrative map downloaded from the EDIT Geoplatform [27]. Natura 2000 data are indicators of recent efforts to achieve nature protection and may not be representative of historic or overall actions to protect nature, as the Natura 2000 reserve selection focused on regions with low presence of already available protection (i.e. National and Regional parks). Data on the number of vascular plant taxa (including subspecies) recorded for each department were obtained in 2012 from the Tela Botanica website (http://www.telabotanica.org/page:chorologie?format=html). Given the relatively low number of data points, we avoided including an excessive number of explanatory variables; further biogeographic factors could be considered in future analyses, including distance from the sea and road density.

Multivariate models were run in Spatial Analysis for Macroecology (SAM) [28]. Given that spatial autocorrelation can reduce the effective degrees of freedom, thus leading to potentially misleading $P$-values [29], the analysis was performed both without (Linear Regression Model) and with controlling (Spatial Autoregression, Generalized Least Squares, with a Gaussian Model for the residual spatial component) for spatial autocorrelation [30,31]. All variables (apart from latitude and longitude) were log-transformed prior to analysis so as to better approach a normal distribution. Non-significant variables (at $p>0.05$ ) were kept in the models to demonstrate that they were not significant predictors. The significance of the significant factors was robust against model reduction. We did not observe strong collinearity (correlation coefficient $>0.70$ ) among the explanatory variables, with the only exception of connectivity and plant biodiversity (correlation coefficient $=0.75$ ).

\section{Results}

Without controlling for spatial autocorrelation, the proportion of organic farming in French departments increased significantly with decreasing latitude and increasing department area. There was no significant association with plant biodiversity, proportion of protected areas, connectivity, longitude, altitude and human population size (Table 1).

All these results were confirmed when controlling for spatial autocorrelation, although with slightly different $P$-values and parameter estimates (Table 2). On its own, latitude explains about $40 \%$ of the variation among French departments in their proportion of organic farming (Figure 1). Department area on its own explains about $17 \%$ of the variation in proportion of organic farming, but this is largely due to a few data points, i.e. some small departments in the lle-de-France area with very low proportion of organic farming.

Table 1. Results of a General Linear Model for the proportion of agricultural land under organic farming in French Departments (2008) as a function of plant biodiversity, landscape connectivity, proportion of Natura 2000 protected areas, latitude, longitude, altitude, human population size and department area. The number of data points is 95 , the adjusted $\mathrm{R}^{2}$ of the model 0.50 , and the intercept 1.457 (s.e. $=2.074$ ).

\begin{tabular}{lrrrrrrrr}
\hline & N of plant taxa & Landscape connectivity & $\%$ Natura 2000 & Latitude & Longitude & Altitude & Human population & Area \\
\hline parameter estimate & 0.264 & 0.047 & 0.113 & -0.084 & 0.003 & 0.038 & 0.056 & 0.327 \\
s.e. & 0.486 & 0.101 & 0.09 & 0.024 & 0.017 & 0.172 & 0.132 & 0.139 \\
$P$-value & 0.59 & 0.64 & 0.21 & $<\mathbf{0 . 0 0 1}$ & 0.87 & 0.82 & 0.67 & $\mathbf{0 . 0 2}$ \\
\hline
\end{tabular}


Table 2. Results of a Generalized Least Squares model controlling for spatial autocorrelation, for the proportion of agricultural land under organic farming in French Departments (2008) as a function of plant biodiversity, landscape connectivity, proportion of Natura 2000 protected areas, latitude, longitude, altitude, human population size and department area. The number of data points is 95 , the Akaike Criterion Indicator of the model 59.9, and the intercept 1.457 (s.e. $=1.972$ ).

\begin{tabular}{lrrrrrrrr}
\hline & N of plant taxa & Landscape connectivity & $\%$ Natura 2000 & Latitude & Longitude & Altitude & Human population & Area $\left(\mathrm{km}^{2}\right)$ \\
\hline Parameter estimate & 0.264 & 0.047 & 0.113 & -0.084 & 0.003 & 0.038 & 0.056 & 0.327 \\
S.e. & 0.462 & 0.096 & 0.086 & 0.023 & 0.016 & 0.164 & 0.125 & 0.133 \\
$P$-value & 0.57 & 0.63 & 0.19 & $<\mathbf{0 . 0 0 1}$ & 0.87 & 0.81 & 0.65 & $\mathbf{0 . 0 2}$ \\
\hline
\end{tabular}

\section{Discussion}

Several studies have shown the essential role of agroecological approaches, and particularly organic agriculture, for sustainable development [32-34]. Ecological intensification enables an improvement of productivity while at the same time reducing adverse effects on the environment [35-38]. Not only the adoption of organic farming practices, but also research on organic farming has expanded considerably over the last years [20,39-41]. This study provides evidence that biogeographic factors can be associated with patterns in organic farming adoption across regions.

There are three main results of this analysis. First, there are no substantial differences between models of the proportion of organic farming in French departments (i) taking spatial autocorrelation into account, and (ii) not taking it into account. The results of models taking into account spatial correlation are more conservative and should be trusted more than those without taking it into account, but in this case there are only slight differences in parameter estimates and $P$-values.

Second, this result does not imply that there is no spatial autocorrelation in the examined variables. For example, the investigated response variable (the proportion of cultivated land under organic farming) was significantly spatially autocorrelated at short distances, as shown by an analysis of Moran's I (Figure 2). This result is in agreement with previous reports of spatial aggregation and neighbouring effects in the adoption of organic farming within countries [42-45]. To some extent, such spatial aggregation might be due to the underlying spatial autocorrelation of biogeographic factors associated with variation in organic farming adoption. However, there is also an important role of neighbouring effects of e.g. social networks and farmer communities in explaining the spatial aggregation of organic farming.

A third result of this study (which holds when controlling for spatial autocorrelation) is the latitudinal gradient from North to South in French adoption of organic farming. Farmers in the South of France might have switched more easily to organic cultivation because of the larger variety of crops they can cultivate in their climatic and environmental settings. In addition, it could be easier to switch to organic cultivation in viticulture (which is typical in Southern France) than for other crops. Moreover, due to a mix of climatic, edaphic, historical and cultural reasons, Southern French departments tend to be located in regions of less intensive agriculture, thus facilitating the adoption of less intensive agricultural practices [46]. This finding is in agreement with previous analyses in England, Germany, the USA and Sweden, which found that organic farming was more likely to occur in marginal areas, where the loss of production due to organic conversion is relatively small $[20,47,48]$ and in regions with more heterogeneous landscapes [49], thus likely to harbour greater plant biodiversity [50]. However, we did not observe a significant association of organic farming adoption with plant biodiversity. It is also possible that the observed latitudinal gradient in organic farming adoption correlates with other socio-economic factors (e.g. personal beliefs, levels of political and financial support, public perceptions, type of crops) that were not considered here.

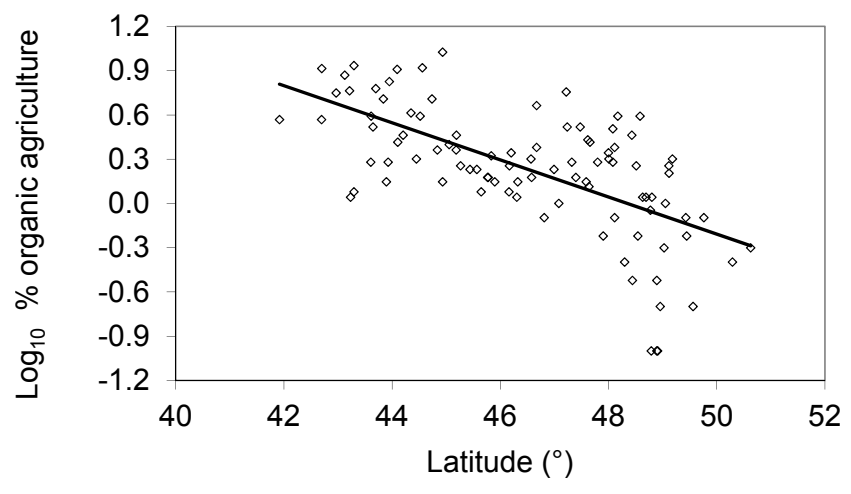

Figure 1. Latitudinal gradient of the proportion of agricultural land under organic farming (logarithmically transformed) in French departments (2008; $\mathrm{n}=95, y=$ $\left.-0.125 x+6.079, R^{2}=0.40, p<0.001\right)$.

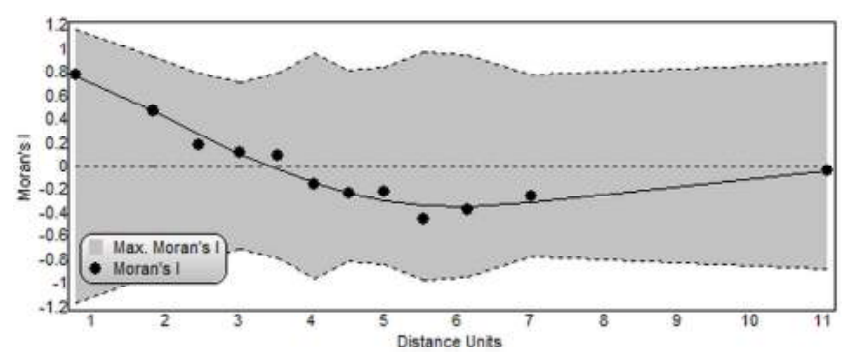

Figure 2. Moran's I for the proportion of agricultural land under organic farming (logarithmically transformed) in French departments (2008). 
Interestingly, although there is generally little variation among French departments in area, this was a significant factor in our analysis, due to the few very small departments (mainly located in the Paris area) having surprisingly low organic farming adoption rates.

Further research should investigate whether biogeographic factors are still significant determinants of organic farming adoption when including a large suite of socioeconomic explanatory variables. Econometric and socioeconomic models of organic farming adoption may benefit from including data on large-scale biogeographic factors. It would also be interesting to use a finer spatial resolution of the data used here, to test for any scale-dependence in the relative importance of biogeographic and socio-economic factors as explanatory variables for organic farming adoption rates.

\section{Conclusions}

Most research on regional patterns of organic farming has focused on socio-economic and cultural factors, from policy support to agglomeration effects and from the philosophy of farmers to the development of markets for organic produce and organic seed [40,51-59]. Whilst these factors are undoubtedly important, this study builds on evidence obtained at the landscape level on the role of environmental factors in shaping organic farming adoption $[20,49]$ and suggests that biogeographic variables may play a contributing role in how widespread organic farming is becoming across entire countries.

\section{Acknowledgements}

Many thanks to V. Chable, O. Holdenrieder, D. McKey and S. Vos for insights and discussions, and to T. Döring, T. Matoni and anonymous reviewers for helpful comments on a previous draft. AMB is supported by Fundação para a Ciência e a Tecnologia through 'FCT Investigator' contract IF/00266/2013 and exploratory project CP1168/CT0001.

\section{References and Notes}

[1] Granatstein D, Kirby E, Willer H, et al. Organic horticulture expands globally. Chronica Horticulturae. 2010;50(4):31-38.

[2] Paull J. The uptake of organic agriculture: A decade of worldwide development. Journal of Social and Development Sciences. $2011 ; 2(3): 111-120$.

[3] Willer H, Lernoud J, Home R. The world of organic agriculture 2013: Summary. In: Willer H, Lernoud J, Kilcher L, editors. The World of Organic Agriculture. Statistics and Emerging Trends. Frick, Switzerland: Research Institute of Organic Agriculture (FiBL) and International Federation of Organic Agriculture Movements (IFOAM); 2013. pp. 26-33.

[4] Schaack D PSWH Lernoud J. The organic market in Europe 2011Nine percent increase compared with 2010. In: Willer H, Lernoud J, Kilcher L, editors. The World of Organic Agriculture. Statistics and Emerging Trends. Frick, Switzerland: Research Institute of Organic Agriculture (FiBL) and International Federation of Organic Agriculture Movements (IFOAM); 2013. pp. 224-229.

[5] Donald PF, Green RE, Heath MF. Agricultural intensification and the collapse of Europe's farmland bird populations. Proceedings of the Royal Society of London B: Biological Sciences. 2001;268(1462):2529. doi:10.1098/rspb.2000.1325.

[6] Stoate C, Báldi A, Beja P, Boatman ND, Herzon I, van Doorn A, et al. Ecological impacts of early 21 st century agricultural change in Europe - A review. Journal of Environmental Management. 2009;91(1):22-46. doi:10.1016/j.jenvman.2009.07.005.

[7] Balmford A, Green R, Phalan B. What conservationists need to know about farming. Proceedings of the Royal Society B: Biological Sciences. 2012;279(1739):2714-2724. doi:10.1098/rspb.2012.0515.

[8] Mader P. Soil fertility and biodiversity in organic farming. Science. 2002;296(5573):1694-1697. doi:10.1126/science.1071148.

[9] Gabriel D, Tscharntke T. Insect pollinated plants benefit from organic farming. Agriculture, Ecosystems \& Environment. 2007;118(1-4):4348. doi:10.1016/j.agee.2006.04.005.

[10] Holzschuh A, Steffan-Dewenter I, Tscharntke T. Agricultural landscapes with organic crops support higher pollinator diversity. Oikos. 2008;117(3):354-361. doi:10.1111/j.2007.0030-1299.16303.x.

[11] Chifflot V, Rivest D, Olivier A, Cogliastro A, Khasa D. Molecular analysis of arbuscular mycorrhizal community structure and spores distribution in tree-based intercropping and forest systems. Agriculture, Ecosystems \& Environment. 2009;131(1-2):32-39. doi:10.1016/j.agee.2008.11.010.

[12] Rundlöf M, Edlund M, Smith HG. Organic farming at local and land- scape scales benefits plant diversity. Ecography. 2009;33(3):514-522. doi:10.1111/j.1600-0587.2009.05938.x.

[13] Tuomisto HL, Hodge ID, Riordan P, Macdonald DW. Does organic farming reduce environmental impacts? - A meta-analysis of European research. Journal of Environmental Management. 2012;112:309-320. doi:10.1016/j.jenvman.2012.08.018.

[14] Tuck SL, Winqvist C, Mota F, Ahnström J, Turnbull LA, Bengtsson J. Land-use intensity and the effects of organic farming on biodiversity: a hierarchical meta-analysis. Journal of Applied Ecology. 2014;51(3):746-755. doi:10.1111/1365-2664.12219.

[15] Schneider MK, Lüscher G, Jeanneret P, Arndorfer M, Ammari Y, Bailey $\mathrm{D}$, et al. Gains to species diversity in organically farmed fields are not propagated at the farm level. Nature Communications. 2014;5. doi:10.1038/ncomms5151.

[16] Lamine C, Bellon S. Conversion to organic farming: a multidimensional research object at the crossroads of agricultural and social sciences. A review. Agronomy for Sustainable Development. 2009;29(1):97-112. doi:10.1051/agro:2008007.

[17] Schmidtner E, Lippert C, Dabbert S. Haben Nachbarschaftseffekte einen Einfluss auf die räumliche Verteilung des Öko-Landbaus in Deutschland? 20. Jahrestagung der Österreichischen Gesellschaft für Agrarökonomie. In: Land-und Ernährungswirtschaft 2020. Vienna, Austria: Universität für Bodenkultur; 2010. pp. 109-110.

[18] Kaufmann P, Zemeckis R, Skulskis V, Kairyte E, Stagl S. The diffusion of organic farming in Lithuania. Journal of Sustainable Agriculture. 2011;35(5):522-549. doi:10.1080/10440046.2011.579838.

[19] Ilbery B, Kirwan J, Maye D. Explaining regional and local differences in organic farming in England and Wales: A comparison of South West Wales and South East England. Regional Studies. 2014;50(1):110-123. doi:10.1080/00343404.2014.895805.

[20] Gabriel D, Carver SJ, Durham H, Kunin WE, Palmer RC, Sait SM, et al. The spatial aggregation of organic farming in England and its underlying environmental correlates. Journal of Applied Ecology. 2009;46(2):323-333. doi:10.1111/j.1365-2664.2009.01624.x.

[21] Bernholt H, Kehlenbeck K, Gebauer J, Buerkert A. Plant species richness and diversity in urban and peri-urban gardens of Niamey, Niger Agroforestry Systems. 2009;77(3):159-179. doi:10.1007/s10457009-9236-8.

[22] Pecher C, Fritz SA, Marini L, Fontaneto D, Pautasso M. Scaledependence of the correlation between human population and the species richness of stream macro-invertebrates. Basic and Applied Ecology. 2010;11(3):272-280. doi:10.1016/..baae.2009.09.005.

[23] Freeman J. Domesticated crop richness in human subsistence cul- 
tivation systems: a test of macroecological and economic determinants. Global Ecology and Biogeography. 2011;21(4):428-440. doi:10.1111/j.1466-8238.2011.00687.x.

[24] de Grenade R, Nabhan GP. Baja California peninsula oases: An agro-biodiversity of isolation and integration. Applied Geography. 2013;41:24-35. doi:10.1016/j.apgeog.2013.03.008

[25] Hijmans RJ, Cameron SE, Parra JL, Jones PG, Jarvis A. Very high resolution interpolated climate surfaces for global land areas. International Journal of Climatology. 2005;25(15):1965-1978. Data available from: http://www.worldclim.org. doi:10.1002/joc.1276.

[26] QGIS Development Team. QGIS Geographic Information System; 2014. Available from: http://qgis.osgeo.org.

[27] Sastre P, Roca P, Lobo JM. A Geoplatform for improving accessibility to environmental cartography. Journal of Biogeography. 2009;36(3):568-568. doi:10.1111/j.1365-2699.2008.02070.x

[28] Rangel TF, Diniz-Filho JAF, Bini LM. SAM: a comprehensive application for Spatial Analysis in Macroecology. Ecography. 2010;33(1):4650. doi:10.1111/j.1600-0587.2009.06299.x

[29] Dormann CF. Effects of incorporating spatial autocorrelation into the analysis of species distribution data. Global Ecology and Biogeography. 2007;16(2):129-138. doi:10.1111/j.1466-8238.2006.00279.x.

[30] Pautasso M, Zotti M. Macrofungal taxa and human population in Italy's regions. Biodiversity and Conservation. 2008;18(2):473-485. doi:10.1007/s10531-008-9511-4.

[31] Cantarello E, Steck CE, Fontana P, Fontaneto D, Marini L, Pautasso M. A multi-scale study of Orthoptera species richness and human population size controlling for sampling effort. Naturwissenschaften. 2009;97(3):265-271. doi:10.1007/s00114-009-0636-4.

[32] Geertsema W, Rossing WA, Landis DA, Bianchi FJ, van Rijn PC, Schaminée $\mathrm{JH}$, et al. Actionable knowledge for ecological intensification of agriculture. Frontiers in Ecology and the Environment. 2016;14(4):209-216. doi:10.1002/fee.1258.

[33] Gomiero T, Pimentel D, Paoletti MG. Environmental impact of different agricultural management practices: Conventional vs. organic agriculture. Critical Reviews in Plant Sciences. 2011;30(1-2):95-124. doi:10.1080/07352689.2011.554355.

[34] Wolf BM, Häring AM, Heß J. Strategies towards evaluation beyond scientific impact. Pathways not only for agricultural Research. Organic Farming. 2015;1(1). doi:10.12924/of2015.01010003.

[35] Watson CA, Atkinson D, Gosling P, Jackson LR, Rayns FW. Managing soil fertility in organic farming systems. Soil Use and Management. 2006;18:239-247. doi:10.1111/j.1475-2743.2002.tb00265.x.

[36] Kassam A, Friedrich T. Nutrient management in conservation agriculture: a biologically-based approach to sustainable production intensification. In: 7th Conservation Agriculture Conference. Dnipropetrovsk, Ukraine; 2009. pp. 1-20.

[37] Scialabba NEH, Müller-Lindenlauf M. Organic agriculture and climate change. Renewable Agriculture and Food Systems. 2010;25(02):158169. doi:10.1017/s1742170510000116.

[38] Smith LG, Williams AG, Pearce BD. The energy efficiency of organic agriculture: A review. Renewable Agriculture and Food Systems. 2014;30(03):280-301. doi:10.1017/s1742170513000471.

[39] Siegmeier T, Möller D. Mapping research at the intersection of organic farming and bioenergy - A scientometric review. Renewable and Sustainable Energy Reviews. 2013;25:197-204. doi:10.1016/j.rser.2013.04.025.

[40] Döring TF. A fresh start for organic farming research. 2013;1(1):1-2. doi:10.12924/of2014.01010001.

[41] Aleixandre JL, Aleixandre-Tudó JL, Bolaños-Pizarro M, AleixandreBenavent R. Mapping the scientific research in organic farming: a bibliometric review. Scientometrics. 2015;105(1):295-309. doi:10.1007/s11192-015-1677-4.

[42] Schmidtner E, Lippert C, Engler B, Haring AM, Aurbacher J, Dabbert S. Spatial distribution of organic farming in Germany: does neighbourhood matter? European Review of Agricultural Economics.
2011;39(4):661-683. doi:10.1093/erae/jbr047.

[43] Lapple D, Kelley H. Spatial dependence in the adoption of organic drystock farming in Ireland. European Review of Agricultural Economics. 2014;42(2):315-337. doi:10.1093/erae/jbu024.

[44] Wollni M, Andersson C. Spatial patterns of organic agriculture adoption: Evidence from Honduras. Ecological Economics. 2014;97:120128. doi:10.1016/j.ecolecon.2013.11.010.

[45] Yang AL, Rounsevell MDA, Wilson RM, Haggett C. Spatial analysis of agri-environmental policy uptake and expenditure in Scotland. Journal of Environmental Management. 2014;133:104-115. doi:10.1016/j.jenvman.2013.11.038.

[46] Teillard F, Allaire G, Cahuzac E, Léger F, Maigné E, Tichit M. A novel method for mapping agricultural intensity reveals its spatial aggregation: Implications for conservation policies. Agriculture, Ecosystems \& Environment. 2012;149:135-143. doi:10.1016/j.agee.2011.12.018.

[47] Kostandini G, Mykerezi E, Tanellari E. Viability of organic production in rural counties: county and state-level evidence from the United States. Journal of Agricultural and Applied Economics. 2011;43(03):443-451.

[48] Rundölf M, Smith HG. The effect of organic farming on butterfly diversity depends on landscape context. Journal of Applied Ecology. 2006;43(6):1121-1127. doi:10.1111/j.1365-2664.2006.01233.x.

[49] Norton L, Johnson P, Joys A, Stuart R, Chamberlain D, Feber R, et al. Consequences of organic and non-organic farming practices for field, farm and landscape complexity. Agriculture, Ecosystems \& Environment. 2009;129(1-3):221-227. doi:10.1016/j.agee.2008.09.002.

[50] Bredemeier B, Rüter S, von Haaren C, Reich M, Schaarschmidt F Spatial congruence between organic farming and biodiversity related landscape features in Germany. International Journal of Biodiversity Science, Ecosystem Services \& Management. 2015;11(4):330-340. doi:10.1080/21513732.2015.1094515.

[51] Padel S. Conversion to organic farming: A typical example of the diffusion of an innovation? Sociologia Ruralis. 2001;41(1):40-61. doi:10.1111/1467-9523.00169.

[52] Koesling $\mathrm{M}$, Flaten $\mathrm{O}$, Lien $\mathrm{G}$. Factors influencing the conversion to organic farming in Norway. IJARGE. 2008;7(1-2):78-95. doi:10.1504/ijarge.2008.016981.

[53] Geniaux G, Lambert M, Bellon S. Analyse de la diffusion spatiale de l'agriculture biologique en région Provence-Alpes-Côte d'Azur (Paca): construction d'une méthodologie d'observation et de prospective. Innovations Agronomiques. 2009;4:417-426.

[54] Döring TF, Bocci R, Hitchings R, Howlett S, van Bueren ETL, Pautasso $M$, et al. The organic seed regulations framework in Europe-Current status and recommendations for future development. Organic Agriculture. 2012;2(3-4):173-183. doi:10.1007/s13165-012-0034-7.

[55] Allaire G, Cahuzac É, Poméon T, Simioni M. Approche spatiale de la conversion à l'agriculture biologique. Les dynamiques régionales en France. Économie rurale. 2014;(339-340):9-31. doi:10.4000/economierurale.4200.

[56] Latruffe L, Nauges C. Technical efficiency and conversion to organic farming: the case of France. European Review of Agricultural Economics. 2013;41(2):227-253. doi:10.1093/erae/jbt024.

[57] Allaire G, Poméon T, Maigné E, Cahuzac E, Simioni M, Desjeux Y. Territorial analysis of the diffusion of organic farming in France: Between heterogeneity and spatial dependence. Ecological Indicators. 2015;59:70-81. doi:10.1016/j.ecolind.2015.03.009.

[58] Home R, Ries E, Tschanz A, Indermühle A. Social factors in the decision by Swiss farmers to convert to organic farming. Acta Fytotechnica et Zootecnica. 2015;18(Special Issue):154-156. doi:10.15414/afz.2015.18.si.154-156.

[59] Boncinelli F, Bartolini F, Brunori G, Casini L. Spatial analysis of the participation in agri-environment measures for organic farming. Renewable Agriculture and Food Systems. 2015; doi:10.1017/s1742170515000307. 